\title{
(Research Article) \\ Biodiesel Production from Waste Cooking Oils by Transesterification Process Using Alkaline Catalysts
}

\author{
Sagar S. Kanjiya ${ }^{1 *}$, Darshit S. Dadhaniya ${ }^{2}$, Bhavin J. Vegada ${ }^{3}$, Dr. A. J. Makadia ${ }^{4}$, Dr. R. L. Patel ${ }^{5}$ \\ ${ }^{1 *}$ M.E. Thermal Engineering, Darshan Institute of Engineering \& Technology Rajkot, Gujarat, INDIA \\ ${ }^{2,3,4}$ Department of Mechanical Engineering, Darshan Institute of Engineering \& Technology Rajkot, Gujarat, INDIA \\ ${ }^{5}$ Department of Mechanical Engineering, Government Engineering College Rajkot, Gujarat, INDIA
}

\begin{abstract}
Waste cooking oil (WCO) is typically cheaper than diesel fuel and has much less impact on food-chain, so its use as biodiesel can reduce the cost of diesel run operations. Restaurants in Rajkot city generate500 gm to $5 \mathrm{~kg}$ of WCO per day. Recycling part of the waste cooking oils in the form of biodiesel can reduce the need of diesel fuel and also reduce import bill of country. Alkaline catalysts transesterification of waste cooking oils, collected within Rajkot City, with methanol was carried out in a laboratory. The effects of methanol/waste cooking oils ratio, potassium hydroxide concentration and temperature on the biodiesel conversion were investigated. Biodiesel yield of $88-90 \%$ was obtained at the methanol/oil ratios of 7:1-8:1, temperatures of $30-50{ }^{\circ} \mathrm{C}$ and $8 \mathrm{gm} \mathrm{KOH}$. Biodiesel and its blends with diesel were characterized for their physical properties referring to a substitute for diesel fuel. The results showed that the biodiesel experienced a higher but much narrower boiling range than conventional diesel. Blends with a percentage of the biodiesel below $30 \mathrm{vol} \%$ had their physical properties within EN14214 standard, which indicated that these could be used in engines without a major modification.
\end{abstract}

Keywords: Waste cooking oil, Transesterification, Biodiesel, Cost effectiveness, Biodiesel blends

\section{Introduction}

Fast depletion of fossil fuels is demanding an urgent need to carry out research work to find out the viable alternative fuels. Diesel fuel is largely consumed by the transportation sector. Therefore, to increase energy security for economic development, alternative source of energy such as biodiesel is necessary $^{[1,2]}$. Biodiesel is renewable, sustainable, biodegradable, and emits low greenhouse gases ${ }^{[3,4]}$. As well, the oxygen content of $11-15 \%$ in the molecular structure speed up the combustion process in compression ignition engines and decreases pollutants such as soot, fine particles, and carbon monoxide $(\mathrm{CO})^{[5,6]}$. Thus, biodiesel is a potential substitute to replace/supplement petro-diesel fuel ${ }^{[7,8]}$.

However, the raw material costs and limited availability of vegetable oil feedstocks are always critical issues for the biodiesel production. The high cost of vegetable oils, which could be up to $75 \%$ of the total manufacturing cost, has led to the production costs of biodiesel becoming approximately 1.5 times higher than that for diesel ${ }^{[9,10]}$.

*Corresponding Author: e-mail: sagarkumar.kanjiya@darshan.ac.in, Tel-+91-9408040240, +91-9727747319

ISSN 2320-7590

(C) 2019 Darshan Institute of Engg. \& Tech., All rights reserved
Nevertheless, the price of waste cooking oils (WCO) is 2-3 times cheaper than virgin vegetable oils. Consequently, the total manufacturing cost of biodiesel can be significantly reduced $^{[10]}$.In addition, a similarity in the quality of biodiesel derived from WCO and from vegetable oils could be achieved at an optimum operating condition ${ }^{[11]}$.Increasing food consumption has increased the production of a large amount of waste cooking oils/fats. However, the optimum conditions for biodiesel production (methanol/oils ratio and concentration of catalyst) are inconsistent. They strongly depend on the properties of WCO. Dorado et al. ${ }^{[12]}$ found that the ester yield reached $90 \%$ at the methanol/oil ratio of 3.48:1 and $1.26 \mathrm{wt} \% \mathrm{KOH}$; while Encinar etal. ${ }^{[13]}$ revealed that the best results obtained at the molar ratio of $6: 1$ and 1 $\mathrm{wt} \% \mathrm{KOH}$.

Alkali catalysts used in transesterification can be potassium hydroxide, sodium hydroxide or alkali methoxides. However, potassium hydroxide was considered as a best catalyst for transesterification of waste cooking oils ${ }^{[13]}$. In this study, the transesterification of WCO was carried out for a reaction temperature of up to $50-60{ }^{\circ} \mathrm{C}$. The molar ratio of methanol/WCO ranged from 7:1 to $8: 1$ in the presence of $\mathrm{KOH}$ catalyst concentration $8 \mathrm{gm}$. 


\section{Biodiesel production}

2.1 Material: WCO samples were collected from restaurants in Rajkot city. It is filtered to remove inorganic residues.Acid values of the samples varied from 1.66 to $1.69 \mathrm{mg} / \mathrm{gm}$. The acid value was relatively low in the sample 2 .The low level of free fatty acid content in the WCO samplescould be an advantageous for an alkali catalyzed transesterificationprocess.

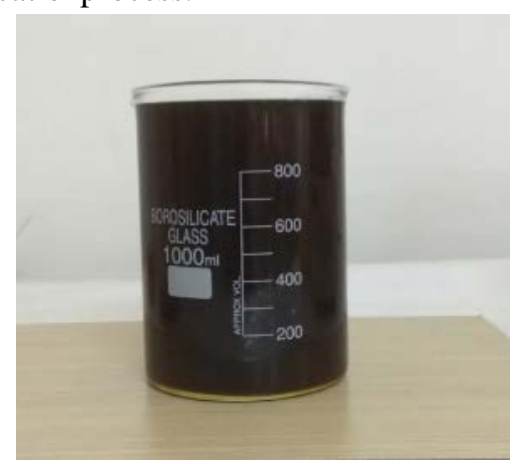

Figure 1. Sample of WCO

Table-1 Physical properties of WCO samples

\begin{tabular}{|c|l|l|l|}
\hline Sr. No. & Properties & Sample 1 & Sample 2 \\
\hline 1 & Acid Value & $1.69 \mathrm{mg} / \mathrm{gm}$ & $1.66 \mathrm{mg} / \mathrm{gm}$ \\
\hline 2 & Density & $0.9 \mathrm{~g} / \mathrm{cm}^{3}$ & $0.88 \mathrm{~g} / \mathrm{cm}^{3}$ \\
\hline 3 & Iodine Value & $54.8 \mathrm{mg} / \mathrm{gm}$ & $88 \mathrm{mg} / \mathrm{gm}$ \\
\hline 4 & Flash Point & $230^{\circ} \mathrm{C}$ & $284^{\circ} \mathrm{C}$ \\
\hline 5 & Cloud Point & $21^{\circ} \mathrm{C}$ & $17^{\circ} \mathrm{C}$ \\
\hline 6 & Pour Point & $22.7^{\circ} \mathrm{C}$ & $14^{\circ} \mathrm{C}$ \\
\hline 7 & Viscosity & $34.2 \mathrm{~mm}^{2} / \mathrm{s}$ & $30.05 \mathrm{~mm}^{2} / \mathrm{s}$ \\
\hline
\end{tabular}

2.2 Transesterification: The transesterification was carried out in a glassflask filled with $1000 \mathrm{ml}$ WCO and $400 \mathrm{ml}$ methanol dissolved with $8 \mathrm{gm} \mathrm{KOH}$. The mixture was heated using magnetic stirrer with hot plate at $45-50{ }^{\circ} \mathrm{C}$ for 1.5 to 2 hours.

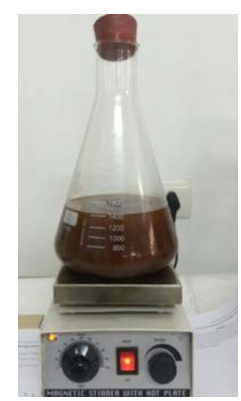

Figure 2 Heating of WCO and methanol mixture

After a certain time, the mixture was poured into a separating funnel. The ester layer was separated by gravity and located in the upper layer. The glycerol, extra methanol and undesired products were in the lower layer and were decanted.

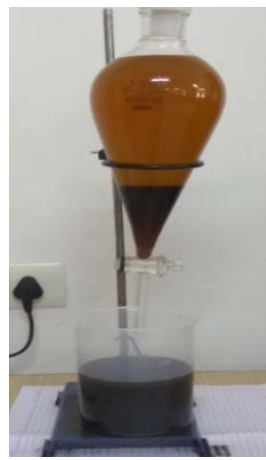

Figure 3. Separation of ester from waste

The ester layer was washed several times with a small amount of hot water each until the washings were neutral.

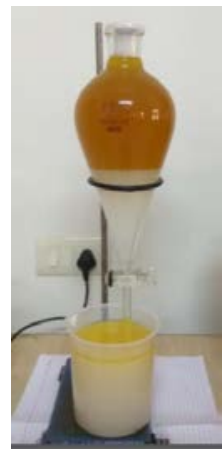

Figure 4. Water washing of ester layer

The nature of catalyst employed during transesterification reaction is crucial in converting triglycerides to biodiesel. As a result different catalysts have being explored for converting triglycerides to biodiesel fuel.The catalysts usually employed to catalyze transesterification reaction are homogeneous catalysts and heterogeneous catalysts. Conventionally, homogeneous alkaline catalysts such as $\mathrm{NaOH}, \mathrm{KOH}$, $\mathrm{CH}_{3} \mathrm{ONa}$,are more often used in producing biodiesel ${ }^{[15]}$.Among these homogeneous alkaline catalysts, $\mathrm{CH}_{3} \mathrm{ONa}$ is most active, providing biodiesel yield above $98 \mathrm{wt} \%$ in short reaction time (30 min) ${ }^{[16,17]}$.However because of low price, industrial biodiesel production process mostly employs $\mathrm{NaOH}$ and $\mathrm{KOH}^{[18]}$.

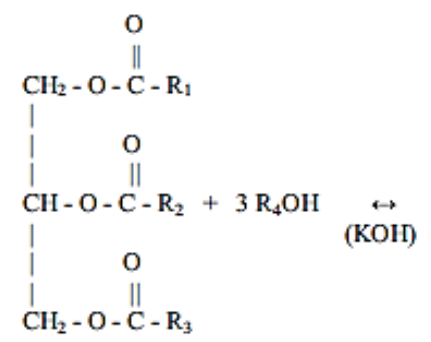

Alcohol
Triglyceride

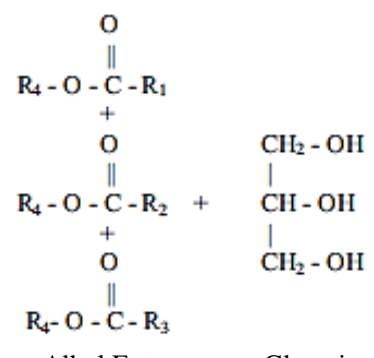

Alkyl Esters
Glycerin
Figure 5. Transesterification reaction of triglycerides via alkaline catalyst 
The process involving these catalysts needs high-quality feedstocks, thus the free fatty acid (FFAs) level of the feedstocks should not exceed 3 wt\%, beyond which the reaction will not occur. In addition, water content of the feedstocks is critical, as a result the feedstocks used in alkalicatalyzed transesterification have to anhydrous ${ }^{[18,19]}$.Thus, presence of water leads to hydrolysis of oils to FFAs. Figure 6 shows water hydrolysis of fats and oils to formfree fatty acid.

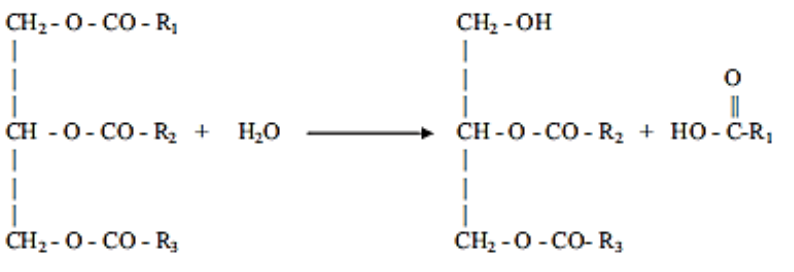

Triglyceride Water Diglyceride Free fatty acid

Figure 6. Water hydrolysis of fats and oils to form free fatty acid (FFAs).

The FFAs react with alkaline catalysts to produce soaps formation. Figure 7 presents soaps formation in homogeneous alkali-catalyzed transesterification. Soaps formation consumes the catalyst, deactivates it and makes biodiesel purification process difficult ${ }^{[15,20]}$.

$$
\begin{array}{ll}
\stackrel{\mathrm{O}}{\|} \underset{\mathrm{ROH}}{\mathrm{R}_{1}-\mathrm{C}-\mathrm{OH}} \\
\text { Free fatty acid } & \text { Potassium hydroxide (Soap) }
\end{array}
$$

Figure 7. Soap formation in homogeneous alkali-catalyzed transesterification

Therefore, preparation of biodiesel by low quality feedstocks containing huge quantity of FFAs and water needs sound technology ${ }^{21]}$. However, high cost of refined feedstocks result in high price of biodiesel compared to diesel fuel ${ }^{[16,22]}$. The cost of refined feedstocks, account to over $70 \%$ of the overall cost of biodiesel production ${ }^{[23]}$.As a result, different kinds of low quality feedstocks such as: waste cooking oils, used cooking oil, greases (yellow and brown), and non-edible oils have being investigated ${ }^{[15,24]}$.The price of low quality feedstocks such as waste cooking oil is 2-3 times lower than refined oils.

Nonetheless, the feedstocks contains higher amount of FFAs and water contents. This features makes their processing challenging ${ }^{[25,26]}$. Therefore to augment their processing difficulties, acid-catalyzed transesterification is first employed to decrease the content of FFAs before performing alkali-catalyzed transesterification ${ }^{[21]}$.

\section{Result and discussion}

\subsection{Process variables in transesterification}

3.1.1. Oil Temperature: The temperature to which oil is heated before mixing with catalyst and methanol, affects the reaction. It was observed that increase in oil temperature marginally increases the percentage oil to bio-diesel conversion as well as the bio-diesel recovery. Experiment conducted at $45-50^{\circ} \mathrm{C}$ temperature and above $50{ }^{\circ} \mathrm{C}$ temperatures methanol loss in process.

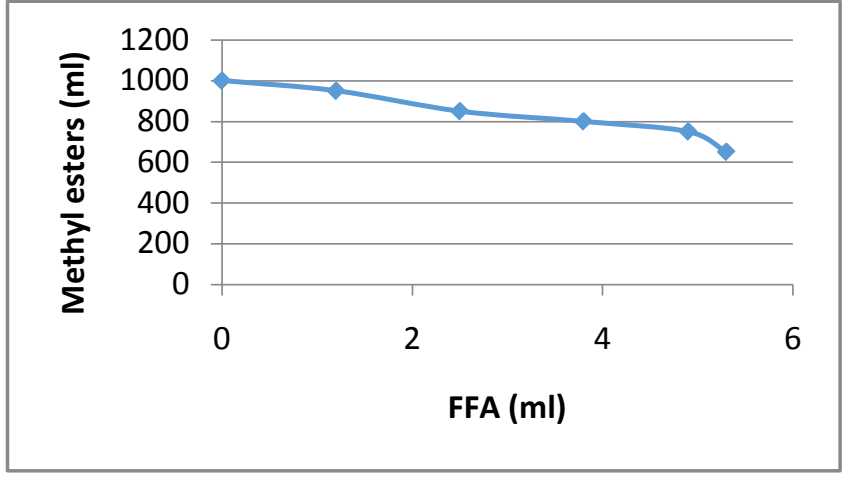

Figure 8. Methyl esters yield against FFA in transesterification reaction

3.1.2. Reaction temperature: The rate of reaction is strongly influenced by the reaction temperature. Generally, thereaction is conducted close to the boiling point of methanol (50 to $60^{\circ} \mathrm{C}$ ) at atmospheric pressure. The experiment conducted at temperatures ranging from 50 to $60^{\circ} \mathrm{C}$ at a molar ratio (alcohol 1 to oil) of 7:1-8:1. Further increase in temperature is reported to have a negative effect on the conversion. Studies have indicated that given enough time, transesterification can proceed satisfactorily at ambient temperatures in the case of the alkaline catalyst.

3.1.3. Ratio of alcohol to oil: Another important variable affecting the yield of ester is the molar ratio of alcohol tovegetable oil. A molar ratio of 6:1 is normally used in industrial processes to obtain methyl ester yields higher than $98 \%$ by weight. The experiment conducted two different molar ratios of 7:1-8:1. It was observed that lower molar ratio7:1 required more reaction time. With higher molar ratio 8:1, conversion increased but recovery decreased due to poor separation of glycerol. It was found that optimum molar ratios depend upon type \& quality of oil.

3.1.4. Catalyst type and concentration: Alkali metal alkoxides are the most effective transesterification catalyst compared to theacidic catalyst. Sodium alkoxides are among the most efficient catalysts used for this purpose, although potassium hydroxide and sodium hydroxide can also be used. Transmethylations occur many folds faster in the presence of an alkaline catalyst than those catalysed by the same amount of acidic catalyst. Most commercial transesterifications are conducted with alkaline catalysts. The experiment conducted 
using alkaline catalyst $(\mathrm{KOH})$ concentration in the range of 0.5 to $1 \%$ by weight yields 94 to $99 \%$ conversion of vegetable oil into esters. Further, increase in catalyst concentration does not increase the conversion and it adds to extra costs because it is necessary to remove it from the reaction medium at the end.

Table-2 WCO and operating parameters for biodiesel production

\begin{tabular}{|l|l|}
\hline Method & Transesterification \\
\hline Temp & $45-50^{\circ} \mathrm{C}$ \\
\hline Time & $1-1.5 \mathrm{hr}$ \\
\hline Volume of WCO & $1000 \mathrm{ml}$ \\
\hline Volume of Methanol & $400 \mathrm{ml}$ \\
\hline Catalyst & $8 \mathrm{gm} \mathrm{KOH}$ \\
\hline Biodiesel & $1000 \mathrm{ml}$ \\
\hline Waste & $400 \mathrm{ml}$ \\
\hline Cost & Rs. $55-60$ per liter \\
\hline
\end{tabular}

Table-3 Properties of biodiesel blend with diesel

\begin{tabular}{|l|c|c|c|c|c|}
\hline Properties & B20 & B40 & B60 & B80 & B100 \\
\hline $\begin{array}{l}\text { Density } \\
\left(\mathrm{kg} / \mathrm{m}^{3}\right)\end{array}$ & 821 & 824 & 828 & 832 & 860 \\
\hline $\begin{array}{l}\text { Viscosity } \\
\left(\mathrm{mm}^{2} / \mathrm{s}\right)\end{array}$ & 3.5 & 3.7 & 3.9 & 4.2 & 4.6 \\
\hline $\mathrm{CV} \mathrm{(kJ/kg)}$ & 40690 & 39120 & 37980 & 36190 & 35570 \\
\hline
\end{tabular}

\section{Nomenclature}

\begin{tabular}{ll}
\hline B20 & Biodiesel blend containing $20 \%$ biodiesel \\
B40 & Biodiesel blend containing $40 \%$ biodiesel \\
B60 & Biodiesel blend containing $60 \%$ biodiesel \\
B80 & Biodiesel blend containing $80 \%$ biodiesel \\
B100 & Biodiesel blend containing 100\% biodiesel \\
\hline
\end{tabular}

\section{Conclusion}

Although being collected from different sources, there was littledifference in properties among the WCO samples in terms of chemicaland physical properties. This could then assist the implementationof biodiesel production process from waste cooking oils. In thisstudy, biodiesel production from the WCO was carried out in thelaboratory glass flask. The results showed that the highest yieldof biodiesel was obtained at the ratio of methanol/WCO of 7:18:1 during $80-90 \mathrm{~min}$ at temperatures ranging $45-50{ }^{\circ} \mathrm{C}$ in the presence of $0.75 \mathrm{wt} \% \mathrm{KOH}$. Although most of the physical propertiesof the biodiesel were within standards for diesel fuel and for bio autofuels (EN14214), the carbon residue was much higher in thebiodiesel than in diesel. The carbon residue was $4.0 \mathrm{wt} \%$ for the biodieselbut only $0.05 \mathrm{wt} \%$ for diesel. There was a very narrowrange of boiling temperature for biodiesel. The boiling temperatureremained approximately $330^{\circ} \mathrm{C}$ from $20 \mathrm{vol} \%$ to 70 vol\% fraction.Mixing the biodiesel with diesel improved significantly the volatilityand decreased the carbon deposits at a percentage of biodiesel inthe blends below 50 vol\%. The results obtained showed that theblend of $20 \mathrm{vol} \%$ the biodiesel and 80 vol\% diesel (B20) could be appliedin engines without major modification.

\section{References}

1. K.K. Oh, Y.S. Kim, H.H. Yoon and B.S. Tae, Pretreatment of lignocellulosic biomass using combination of ammonia recycled percolation and dilute-acid process, Journal of Industrial and Engineering Chemistry, Vol. 8, No. 1, pp 64-70, 2002.

2. B.-H. Um and Y.-S. Kim, Review: A chance for Korea to advance algal-biodiesel technology, Journal of Industrial and Engineering Chemistry, Vol. 15, No.1, pp. 1-7, 2009

3. Y.C. Sharma, B. Singh, Advancements in development and characterization of biodiesel: A review, Renewable \& Sustainable Energy Reviews,Vol. 13, 2009.

4. S.B. Lee, K.H. Han, J.D. Lee, I.K. Hong, optimum process and energy density analysis of canola oil biodiesel synthesis, Journal of Industrial and Engineering Chemistry, Vol. 16, 2010.

5. S.B. Lee, J.D. Lee, I.K. Hong, Ultrasonic Energy Effect on Vegetable Oil Based Biodiesel Synthetic Process, Journal of Industrial and Engineering Chemistry, Vol. 17 pp 138, 2011.

6. S.S. Kim, K.H. Kim, S.C. Shin, E.S. Yim, Study of Fuel Properties for Biodiesel Derived from Duck's Oil, Journal of the Korean Industrial and Engineering Chemistry,Vol.18, pp 401, 2007.

7. B. Saeid, M.K. Aroua, A. Abdul Raman, N.M.N. Sulaiman,Prediction of Palm Oil-Based Methyl Ester Biodiesel Density Using Artificial Neural Networks,Journal of Applied Sciences,Vol. 28, 2008.

8. K.R. Szulczyk, B.A. McCarl, Market penetration of biodiesel,Renewable \& Sustainable Energy Reviews, Vol.14,pp 2426-2433, 2010.

9. Ma F, Hanna MA., Biodiesel production: a review, Bioresour Technology, Vol. 70, pp1-15, 1999.

10. Zhang Y, Dube MA, McLean DD, Kates M. Biodiesel production from waste cooking oil: 2 . Economic assessment and sensitivity analysis,Bioresour Technology,pp229-40, 2003.

11. Cetinkaya M, Karaosmanoglu F., Optimisation of base-catalysed transesterification reaction of used cooking oil,Energy Fuels, Vol. 18, pp1888-95, 2004.

12. Dorado MP, Ballesteros E, Lopez FJ, Mittelbach M., Optimisation of alkali catalyzed transesterification of Brassica Carinata oil for biodiesel production,Energy Fuels, Vol. 18,pp. 77-83, 2004.

13. Encinar JM, Gonzalez JF, Rodriguez-Reinares, A. Biodiesel from used frying oil. Variables affecting 
the yields and characteristics of the biodiesel. Ind Eng Chem Res, pp. 5491, 2005.

14. Anh N. Phan a, Tan M. Phan, "Biodiesel production from waste cooking oils”Fuel, Vol. 87,pp. 34903496, 2008.

15. Y.C. Sharma, B. Singh, S.N. Upadhyay, Advancements in development and characterization of biodiesel: A review, Fuel, Vol. 87,pp. 2355, 2008.

16. Z. Helwani, M.R. Othman, N. Aziz, W.J.N. Fernando, J. Kim, Technologies for production of biodiesel focusing on green catalytic techniques: a review, Fuel Processing Technology, Vol. 90, pp 1502, 2009.

17. Demirbas, Progress and recent trends in biodiesel fuels,Energy Conversion and Management, Vol. 50, pp. 14-34, 2009.

18. F. Hideki, K. Akihiko, N. Hideo,Biodiesel fuel production by transesterification of oils,Journal of Bioscience and Bioengineering, Vol.92, pp.405, 2001.

19. Demirbas, A Realistic Fuel for Alternative Diesel Engines, Springer, 2014.

20. J. Van Gerpen, B. Shanks, R. Pruszko, D. Clements, G. Knothe, Biodiesel Production Technology, NREL/SR-510-36244 August 2002-January 2004.
21. S. Chongkhong, C. Tongurai, P. Chetpattananondh, Enzymatic Biodiesel Synthesis Using a Byproduct Obtained from Palm Oil Refining, Renewable Energy, Vol.34 pp. 1059, 2009.

22. K. Bozbas, Biofuel production, Renewable \& Sustainable Energy Reviews, Vol.12,pp.542, 2008.

23. S. Zullaikah, C. Lai, S.R. Vali, Y. Ju, Biodiesel conversion technologies, Bioresource Technology, Vol. 96,pp. 1889, 2005.

24. K.-W. Lee, J.X. Yu, J.H. Mei, L. Yan, Y.-W. Kim, K.-W. Chung, Split addition of enzymes in enzymatic hydrolysis at high solids concentration to increase sugar concentration for bioethanol production, Journal of Industrial and Engineering Chemistry, Vol. 13, pp.799, 2007.

25. M. Balat, H. Balat, Progress in Biodiesel Processing, Applied Energy, Vol. 87, pp. 1815, 2010.

26. T.V. Palligarnai, M. Briggs, Design of a continuous process of biodiesel production, Journal of Industrial Microbiology \& Biotechnology, Vol. 35, pp. 421, 2008.

27. Cetinkaya M, Karaosmanoglu F., Optimisation of base-catalysed transesterification reaction of used cooking oil,Energy Fuels,Vol. 18, pp. 1888-95, 2004.

\section{Biographical notes}

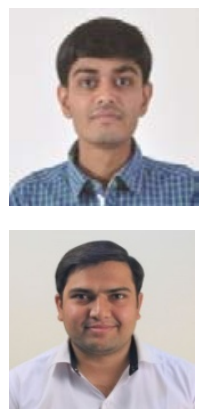

Sagar S. Kanjiya is Pursuing M.E. in Thermal Engineering from Darshan Institute of Engineering \& Technology, Rajkot, Gujarat, India.

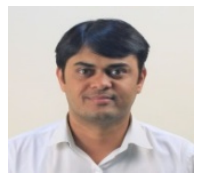

Darshit S. Dadhaniya has received M.E. in Thermal Science from The M. S. University, Vadodara, Gujarat in 2015.He is assistant professor in Mechanical engineering department of Darshan Institute of Engineering \& Technology, Rajkot, and Gujarat, India.

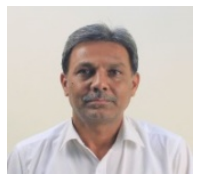

Bhavin J. Vegada has received M.Tech. inThermal from Nirma University in 2011. He is Head of Department-Degree of Mechanical engineering department of Darshan Institute of Engineering \& Technology, Rajkot, Gujarat, India.

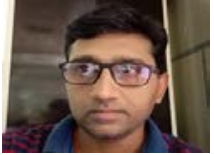

Dr. Ashvin J. Makadia has received M.Tech. in CAD/CAM from Nirma University in 2005 and Ph.D. in mechanical engineering from M. S. University, Baroda, Gujarat in 2015. He is professor of Mechanical engineering department of Darshan Institute of Engineering \& Technology, Rajkot, Gujarat, India.

Dr. Rupesh L. Patel has received Ph.D. in mechanical engineering from RK University, Rajkot, Gujarat in 2017. He is assistant professor of Mechanical engineering department of Government Engineering College, Rajkot, Gujarat, India. 